\title{
The gender gap in the biological living standard in Spain. A study based on the heights of an elite migration to Mexico, 1840-1930
}

\section{Carlos Santiago-Caballero}

Department of Social Sciences, Universidad Carlos III Madrid, Calle Madrid, 126 Getafe, CP: 28903, Madrid, Spain

\section{A R T I C L E I N F O}

\section{Article history:}

Received 11 December 2020

Received in revised form 23 February 2021

Accepted 23 February 2021

Available online 26 February 2021

\section{JEL classifications:}

D6

$\mathrm{J} 24$

NO

N33

015

\section{Keywords:}

Heights

Migrations

Gender gap

\begin{abstract}
A B S T R A C T
This paper examines the evolution of the statures of Spanish male and female migrants who entered Mexico between the mid-nineteenth and the mid-twentieth century. Using the information contained in the National Registry of Foreigners created by the Mexican government, the paper also estimates the evolution of the gap between male and female migrants' heights. The inclusion of women and their heights in the registry allows the estimation of both male and female heights and the analysis of their evolution for a group of comparable individuals. The results show that Spanish migrants to Mexico grew taller between 1840 and 1930, and also reveal their character as a highly qualified group, with heights similar to those of the Latin-American elites and considerably higher than the statures of those who remained in Spain. In the long term, the differences between men and women decreased from more than $10 \mathrm{~cm}$ in the cohorts born in the mid-nineteenth century, to around 8-9 centimetres in the early twentieth century, coinciding with a period of profound economic and social transformations.
\end{abstract}

(c) 2021 The Author. Published by Elsevier B.V. This is an open access article under the CC BY-NC-ND license (http://creativecommons.org/licenses/by-nc-nd/4.0/).

\section{Introduction}

The measurement of living standards in the past has given rise to some of the most intense and controversial debates in academic literature. The disagreements frequently derive from the difficulties involved in finding objective proxies of welfare, and also from the problems to identify which should prevail in the event that they present opposite trends over the same period of time. ${ }^{1}$ In the search for precise biological markers, economic historians turned their interest to the study of heights, under the assumption that changes in stature reflect changes in living conditions, including aspects that could not be captured by other proxies like income. ${ }^{2}$ Several studies have endorsed the usefulness of heights as proxy for a wide range of variables including not only nutrition levels, but also environmental conditions, education, and even cognitive abilities. ${ }^{3}$ It was in the

\footnotetext{
E-mail address: carlos.santiago@uc3m.es (C. Santiago-Caballero).

1 A good example of this is the pessimistic versus optimistic debate concerning the effect of the Industrial Revolution on workers' lives.

2 Steckel (2008) and Komlos and Baten (1998)

${ }^{3}$ For nutrition, see Bodzsár and Susanne (1998) for environmental conditions, Steckel (1995), for education, Quiroga (2003) and Martínez-Carrión and Puche Gil (2010). See also Deaton and Arora (2009); Case and Paxson (2008). There are also studies linking income levels with heights, such as María-Dolores and MartínezCarrión (2011) or Bozzoli et al. (2009).
}

1980s when the estimations of human heights began to be systematically used by economic historians to measure living standards, and the 1982 special issue of Social Science History lent considerable momentum to the development of the discipline. ${ }^{4}$ There was a significant increase in the literature on human heights over the next four decades, following the examples set by the first wave of publications in the eighties. ${ }^{5}$ Since then, the availability of comparable sources and the use of common methodologies has made possible the growth of anthropometric history covering a diverse range of geographical locations and periods of time. ${ }^{6}$ The sources used in the literature are equally diverse, from analysis of skeletons and armour, to the study of records of slaves, prisons or the military. ${ }^{7}$ The new evidence provided also led to profound revision in

\footnotetext{
${ }^{4}$ For example Sandberg and Steckel (1980); Floud and Wachter (1982); Steckel (1983); Martínez-Carrión (1986) or Komlos (1989)

${ }^{5}$ Fogel (1995) presents a good summary of the first studies. For a more recent state of the question, see Komlos (2009); Steckel (2009) and especially Galofré-Vilà (2018)

${ }^{6}$ Although it is impossible to cite all, some examples are, for England, Floud et al. (1990); Nicholas and Steckel (1991) or Hatton and Martin (2010), for Italy, Federico (2003) and A'Hearn (2003). Floud (1994) and Hatton and Bray (2010)) present series for Europe. See also Komlos (1995) for a wide range of studies. As examples of very long-term studies, see Bogin and Keep (1999) and Koepke and Baten (2005) and Floud et al. (2011) for a general view.

7 Steckel and Rose (2002); Steckel (1979), Martínez-Carrión and Puche Gil (2010).
} 
crucial debates from new points of view, such as the evolution of inequality between individuals and territories (Kelly and Baten, 2019). Spain was not an exception in the development of historical anthropometry, and also witnessed a considerable number of investigations at regional and national levels, mainly from the late nineteenth to the mid-twentieth century. ${ }^{8}$

However, most historical anthropometric studies focus on the analysis of males, the main reason being that most of the available sources such as those described above only included information for men. The most iconic example is the use of military recruitment records, where women and in some cases the highest socioeconomic classes were not included. Although the development of the field has also expanded to include historical studies on female heights, their presence in the literature is still comparatively scarce. ${ }^{9}$ This fact reinforces the idea that there is a need for further studies providing quantitative evidence of the evolution of female heights in the past (Galofré-Vilà, 2018:116). Therefore, this paper addresses a key issue: the changes in gender inequality from a historical perspective that, employing an extraordinary source, sheds light on the traditional invisibility of women in history, especially in anthropometric studies. The period covered by the paper adds particular value to the study, as it includes the decades when some of the most substantial economic and social changes in Spanish history took place (Prados de la Escosura and SantiagoCaballero, 2020). What was the impact - positive or negative - of those changes upon the balance between female and male welfare? Did women benefit from the modernisation enjoyed by Spain since the second half of the nineteenth century? The identification strategy of this paper makes it possible to answer some of these questions, providing new quantitative evidence on this crucial topic during a period of crucial historical transformations

This paper attempts to contribute to filling this gap in the literature by providing new evidence with regard to the heights of male and female Spanish migrants to Mexico between the midnineteenth and the mid-twentieth century. For that purpose, we will use the Registro Nacional de Extranjeros (National Registry of Foreigners) in Mexico that includes records of thousands of Spanish migrants who entered the country between 1870 and 1950. The Registry recorded the heights of both males and females, and therefore offers the opportunity to estimate the evolution of heights for both genders, as well as the gender gap in biological standards of living. The first section of the paper will introduce the main primary source used, the National Registry of Foreigners established by the Mexican government in 1926, and describe the sample of observations and its limitations. The second section will explain the methodology followed in the analysis of the data and the creation of the sample. The third part of the paper describes the profile of the Spanish migrants to Mexico, and the fourth section presents the main results, including the average heights of male and female migrants and the gender gap between both, estimated using statistical models. The last section of the paper presents the conclusions.

\footnotetext{
8 Martínez-Carrión (1986) was one of the pioneers of the first wave who covered Spain, followed by other studies by the same author, such as Martínez-Carrión (1991, 1994, 2001, 2005), Martínez-Carrión and Moreno-Lázaro (2007); MartínezCarrión et al (2014); Martínez-Carrión and Salvatore (2019), and to name a few by Quiroga (1998, 2001, 2002, 2003), Gomez Mendoza and Perez Moreda (1995); Cámara (2009); Garcia-Montero (2009) and Ramón-Muñoz (2009). For a detailed summary of the literature of the last decade in Spain, see Martínez-Carrión et al. (2018)

9 Baten and Murray (2000); Harris (2009) or Guntupalli and Baten (2009). With more contemporary data, Murasko (2020) analysed the relationship between women's heights and their role in the marriage market.
}

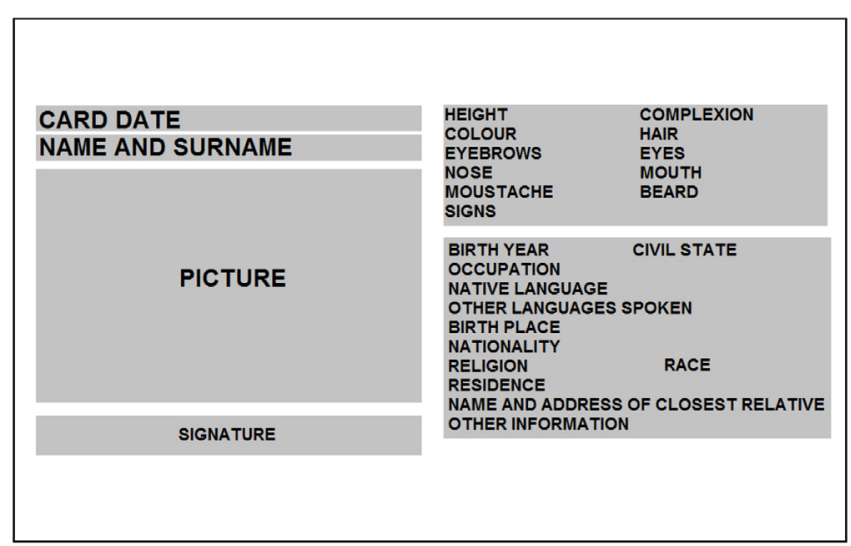

Fig. 1. Immigration Card Design.

\section{Sources}

The National Registry of Foreigners in Mexico (Registro Nacional de Extranjeros, Registry henceforth) was established in Mexico by the national government in 1926. The Registry was controlled by the General Direction of Migratory services and its main purpose was the registration of all the foreigners living in Mexico at the time. For that reason, the national authorities introduced a survey that interviewed all the foreigners who had entered Mexico before 1926 and were still living in the country. The process was slow and most of the records of foreigners already living in Mexico were created in the 1930s. However, the records of all the migrants who entered Mexico after the establishment of the registry were usually issued as they crossed the frontier. The Registry continued to record all incoming migrants until 1948. Personal information about each foreigner was recorded on cards issued as legal proof of their status in the country. Although the design of the cards changed, depending on the entry year, the information provided on them was relatively standard. Fig. 1 shows a typical design of the card and the data it included. ${ }^{10}$

The cards provided extremely detailed physical descriptions of the migrants. They included front and side pictures, height, physical complexion, and information related to skin colour, hair, eyebrows, eyes, nose, mouth, jaw, moustache, beard and other visible features. The card also contained information about the migrant's profile, such as year of birth (sometimes even the day and month), civil status, occupation, native language, other languages spoken, birth place (often including the municipality), nationality, religion, race and last residence. It is worth noting that the card indicates the birthplace and not just the last residence, a fact that is key to identifying the migrant's origin within Spain and therefore where they probably grew up. The card issue date is another key variable in our analysis, because it was also the date when the height of the individual was measured and will be used to adjust the height of older people as explained below. The registry records also included further information, such as the migrant's political status (mainly whether a political refugee or not), place of entry into Mexico, and type of transport employed.

However, although most of the information contained in the cards is standard for every year, we also found some differences in the quality of the information provided in the field "occupation". We believe that the occupation reported by those migrants that

\footnotetext{
${ }^{10}$ An example of a real card is presented in the appendix. The cards were stored in the Archivo General de la Nación (General Archive of the Nation) in Mexico and were digitalised by the Subdirectorate General of State Archives in Spain and are accessible from their web portal www.pares.es.
} 
were already living in Mexico when the registry was created was their occupation in Mexico when they were interviewed. However, in the cases when the cards were issued upon entry into the country, the information referred to the migrant's occupation before leaving Spain. In addition to this important difference, there is also a qualitative disparity in the records. In the cases of migrants who were living in Mexico, a very significant proportion of the occupations reported were either "sales persons" or "employees". The information provided by migrants as they entered Mexico was more detailed, however, and provided a full description of the sort of work they had performed in Spain. We can therefore conclude that either the authorities that interviewed migrants present in Mexico when the registry was created were less diligent than their counterparts in immigration control, or that the Spaniards already living in Mexico offered less precise information than those registered upon entering the country. A third alternative is that the Spaniards in Mexico were indeed mainly working within those two occupations, especially as shopkeepers. In any case, we should also take into account the possibility of underreporting in the occupation by migrants already living in Mexico and the potential limitation in the analysis resulting from the latter.

We transcribed all the cards available, including a total of 26,631 migrants - 18,869 men and 7,762 women - whose years of birth range from the 1840 s to the late 1930s, and who entered Mexico between 1870 and 1950. As explained above, the Registry was established in Mexico in 1926 and the cards were issued for all the migrants who entered the country thereafter. Therefore, we can be sure that the Registry includes all the migrants who entered Mexico between 1926 and 1948. However, for those who entered Mexico previously, we have only the records of those migrants that remained in the country and were still alive or moved somewhere else before they were interviewed by the Mexican authorities. This implies that for the migrants who were already living in Mexico the sample might suffer a survival bias, meaning that the heights for this particular group of migrants could correspond to those who were more successful. In contrast, the bias could also be negative if those who remained in Mexico were those who could not make enough money successfully to return to Spain.

Figs. 2 and 3 show the density histograms of the number of observations in the sample by year of birth for men and women. The richest periods in terms of availability of records are the late nineteenth and early twentieth centuries. We also observe that in the case of both men and women, the histograms follow a normal distribution, with few exceptions such as the overrepresentation of 1870 and similar years, which we believe could be consequence of the well-known practice of rounding up the birth year.

\section{The profile of the Spanish migrant to Mexico}

Who were these migrants and how similar were they to those who remained in Spain? There are good reasons to believe that there was a clear positive selection in the profile of Spanish migrants, although the evidence is not unanimous. On the one hand, Sánchez-Alonso (2019) argued that taking into account literacy rates, southern European migrants to Latin America were positively selected. Juif (2015), on the other hand, shows that in the case of Spanish migrants to Cuba, the selection was actually negative, especially in the case of those from the Canary Islands, as consequence of the promotion of low-skilled migration to replace African slave labour in sugar plantations. In the case of Mexico, Lida and Pacheco Zamudio (1994) explain that Spanish immigrants were considerably better prepared than those who stayed behind. We can confirm their results in our sample, where less than two per cent of the males who reported an occupation were employed in unskilled jobs and almost 20 per cent spoke at least one foreign language. Juif's information with regard to age heaping (2015)

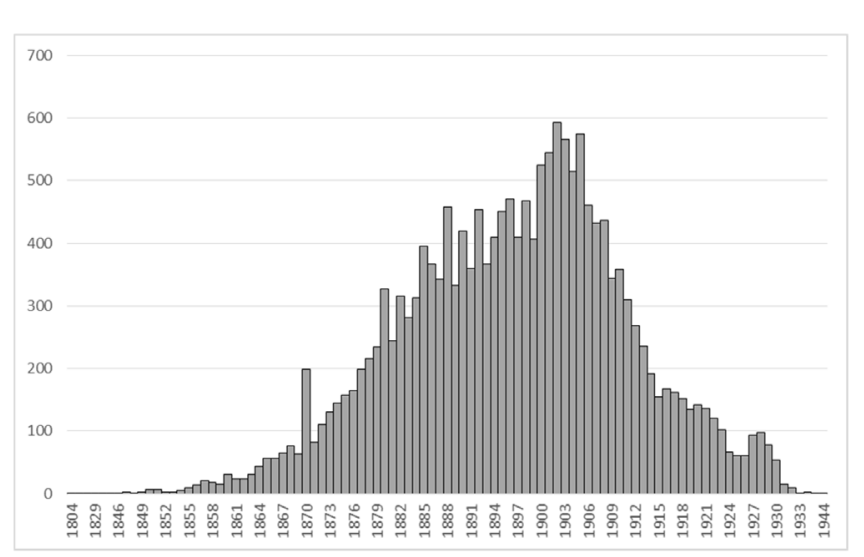

Fig. 2. Number of male records by year of birth. Source: National Registry of Foreigners.

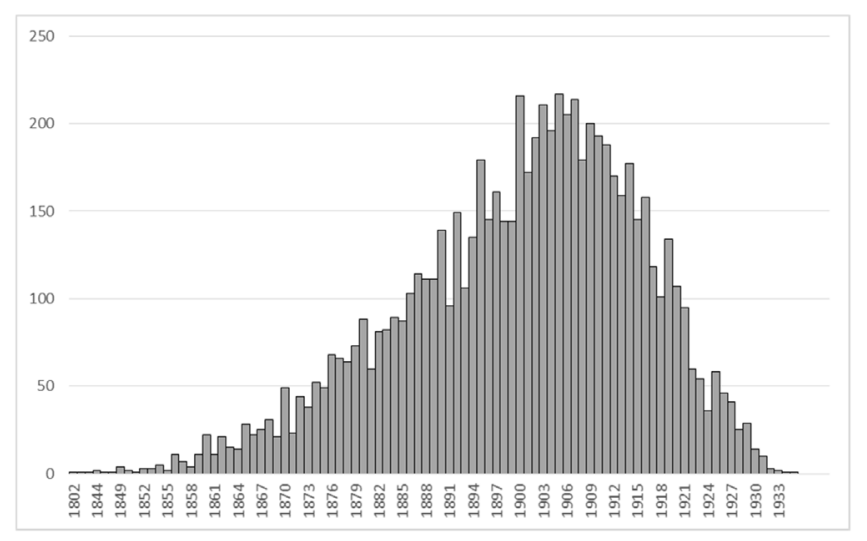

Fig. 3. Number of female records by year of birth. Source: National Registry of Foreigners.

enables us to estimate the degree of positive selection of Spanish migrants to Mexico. Juif calculated that the ABCC index for the cohorts born between 1840 and 1850 was around 90 for the males who remained in the country, and below 90 for male migrants to Cuba. Our estimate for migrants to Mexico born in the same decades indicates ABCC indexes around 97 for males and 92 for women, well above the average levels in Spain, suggesting clear positive selection for both men and women. ${ }^{11}$

For males, this positive selection is more apparent when one analyses the socio-economic background of the migrants reflected by the occupations they reported, categorising them in five different social classes as suggested by Van Leeuwen and Maas (2011) in their five categories HISCLASS classification. The classification ranks occupations from higher lo lower socioeconomic status, starting with class 1 that includes the elites and finishing with class 5 that contains most of the unskilled workers.

As Fig. 4 shows, more than 67 per cent of males belonged to class 2 and 15.5 per cent to class 1 . Only 11.4 per cent of the total worked in occupations associated with the two lowest social classes. The positive selection is reflected not only in their human capital, but also in their height. According to Quiroga (2001), the average height of Spanish conscripts between the 1870s and 1920s was around $164 \mathrm{~cm}$, while the average stature of males included in our sample was four centimetres higher.

\footnotetext{
11 The $A B C C$ index reports values from 0 to 100 based on age heaping, where higher values indicate higher numeracy and therefore higher human capital levels.
} 


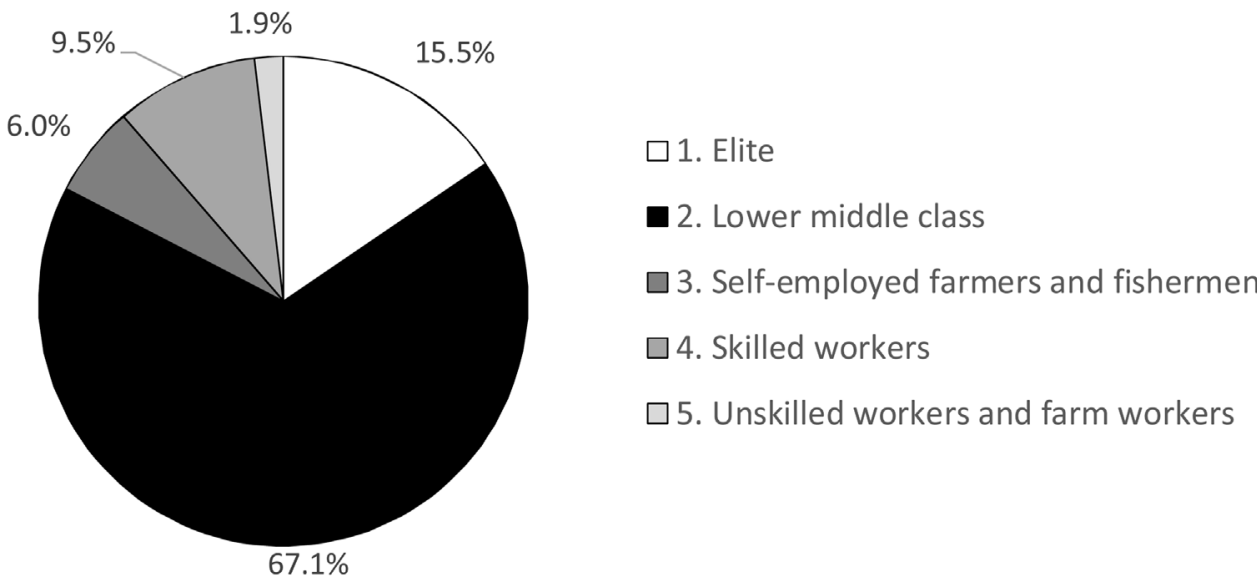

Fig. 4. Class of origin of Spanish migrants to Mexico.

Source: estimated from National Registry of Foreigners using Van Leeuwen and Maas (2011).

Study of the regional origins of the migrants presented in Fig. 5 and Table 1 reveals very clear and defined geographical patterns common to both men and women. The northern coastland regions and Old Castile provided the highest numbers of migrants moving to Mexico, together with Catalonia in the northeast. Followed by Andalusia in the south and Madrid in the centre, with smaller numbers recorded from the rest of the country. The most significant difference between the gender compositions of the Spanish migrants is the percentage of women who moved from Catalonia, higher than the proportion represented by Catalan men. However, taking into account this disparity, the regional origins of both men and women are practically identical every decade. We studied the similarity of the geographical patterns by decade measuring the correlation between the proportion of men and women leaving from each region. The results show that the correlations never fell below 79 per cent. Therefore, some of the regions of Spain are clearly overrepresented in the sample, given their real weight in the total population of the country. However, this bias was consistent during the whole period, implying that it is not necessary to make significant adjustments to allow the comparability of the results for both genders over time in terms of geographical origin.

With respect to the year of arrival, Fig. 6 shows three periods when arrivals were more numerous: the first decade of the twentieth century; the 1920s; and the early and late 1940s. However, we should take into account that given that the Registry was created in the $1920 \mathrm{~s}$, arrivals prior to that decade were estimated from the stock of Spanish migrants already living in Mexico and are underestimated, especially for the earlier years. The other striking feature of the series is the high peak of arrivals in 1939. This peak corresponds to the mass arrival of republican exiles after the end of the Spanish Civil War. Together with France, Mexico became the largest recipient of republican exiles, supported by the government of president Lázaro Cárdenas. As Pla Brugat (2001) explained, republican exiles in Mexico formed a highly skilled population, presenting a very similar profile to Spanish migrants who moved for economic reasons. In this sense, the high quality of the traditional Spanish migrants who moved to
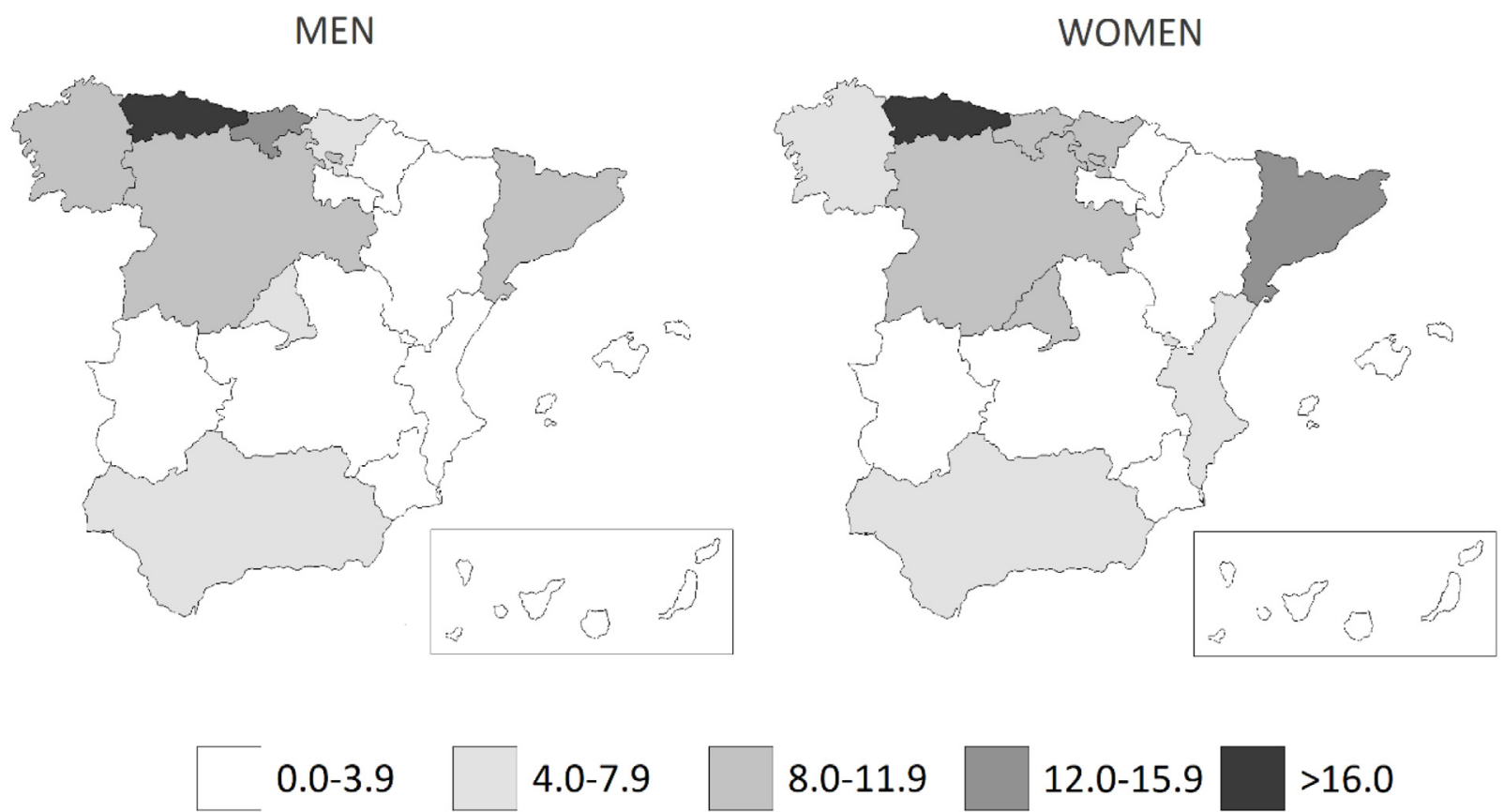

$8.0-11.9$

$12.0-15.9$ 
Table 1

Regions of origin.

\begin{tabular}{|c|c|c|c|c|c|c|c|c|c|}
\hline & $1850-1920$ & 1850 & 1860 & 1870 & 1880 & 1890 & 1900 & 1910 & 1920 \\
\hline Andalusia & 6.4 & 7.5 & 5.9 & 7.2 & 5.5 & 6.3 & 4.9 & 6.9 & 6.8 \\
\hline Aragon & 2.1 & 3.0 & 2.4 & 2.2 & 1.7 & 1.8 & 1.7 & 2.3 & 1.7 \\
\hline Asturias & 22.2 & 21.1 & 20.4 & 22.5 & 24.5 & 25.0 & 25.8 & 18.1 & 20.3 \\
\hline Balearic Islands & 0.8 & 1.5 & 1.1 & 1.3 & 1.1 & 0.5 & 0.3 & 0.7 & 0.2 \\
\hline Canary Islands & 0.8 & 0.8 & 1.3 & 1.2 & 0.6 & 0.7 & 0.5 & 0.7 & 0.6 \\
\hline Cantabria & 12.8 & 13.5 & 14.5 & 12.4 & 14.6 & 13.7 & 13.4 & 9.6 & 10.7 \\
\hline Castilla la Mancha & 1.4 & 1.5 & 1.6 & 1.3 & 0.9 & 0.9 & 1.4 & 2.1 & 1.2 \\
\hline Castilla y León & 10.9 & 10.5 & 11.6 & 12.6 & 12.0 & 11.8 & 11.8 & 8.6 & 8.1 \\
\hline Catalonia & 11.2 & 11.3 & 13.7 & 12.3 & 9.9 & 9.1 & 9.1 & 12.9 & 11.2 \\
\hline Extremadura & 0.8 & 0.0 & 0.8 & 0.4 & 0.5 & 0.7 & 1.0 & 1.6 & 1.1 \\
\hline Galicia & 8.9 & 5.3 & 5.8 & 8.0 & 10.1 & 10.4 & 10.3 & 10.2 & 11.4 \\
\hline La Rioja & 1.2 & 3.0 & 1.4 & 1.4 & 1.0 & 1.1 & 0.6 & 0.5 & 0.4 \\
\hline Madrid & 5.8 & 6.0 & 4.7 & 4.5 & 3.7 & 4.4 & 4.9 & 8.7 & 9.5 \\
\hline Murcia & 0.9 & 0.8 & 1.6 & 0.5 & 0.5 & 0.9 & 1.0 & 0.9 & 1.4 \\
\hline Navarre & 2.8 & 3.0 & 3.2 & 2.7 & 2.8 & 2.3 & 2.6 & 2.9 & 3.0 \\
\hline Basque Country & 7.6 & 6.0 & 7.6 & 6.3 & 7.5 & 7.3 & 7.8 & 9.3 & 8.8 \\
\hline Valencia & 3.5 & 5.3 & 2.4 & 3.2 & 3.1 & 3.2 & 3.1 & 4.2 & 3.5 \\
\hline
\end{tabular}

Source: National Registry of Foreigners.

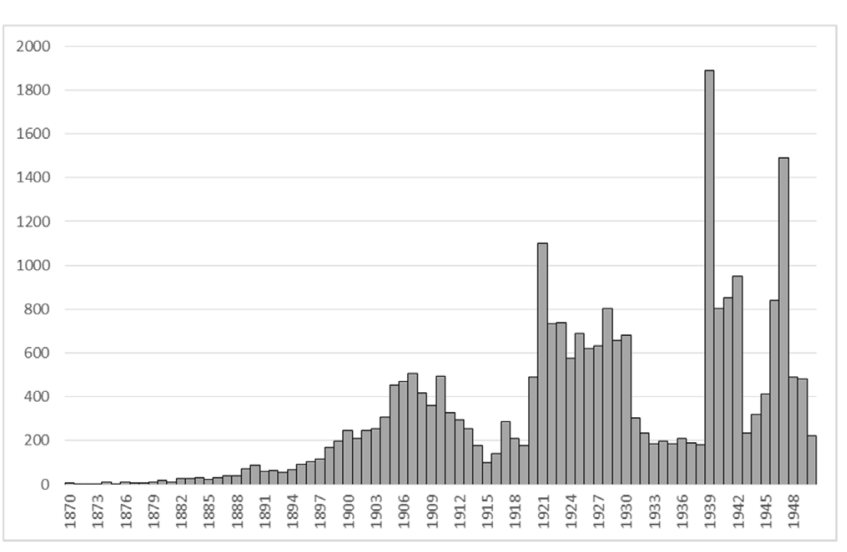

Fig. 6. Distribution of records by entry year, 1870-19. Source: National Registry of Foreigners.

Mexico implied that the arrival of the republican exile represented more a continuation than a disruption in the profile of the migrants.

\section{Estimating heights from the records}

In order to estimate the evolution of the height of Spanish migrants, we calculated decadal averages for both men and women according to their birth cohort. There were several reasons for the decision to estimate statures using 10-year periods. Most importantly, the need to create estimates from samples that were statistically large, a requirement that was especially important in the tails of the time distribution where the number of yearly records is lower. Records are plentiful for the period 1880-1920, when we could even carry out annual estimations at a national level. However, the lack of records for the tails of the time distribution would hinder the elaboration of yearly series large enough to provide robust estimates. There are also sound methodological reasons for using long rather than short periods of time. An individual that has suffered malnutrition during the first years of their life might be able to catch up during the remainder of their youth, especially during puberty. Therefore, the consideration of a longer period of time could help us partially to capture this sort of situation. Finally, the use of decadal cohorts has also been widely used in the literature and is therefore generally accepted as a valid approach, especially when the sample is not large enough to permit the use of shorter time periods. ${ }^{12}$

We performed several calibrations in our estimates, necessary given the nature of the registry, as it measured Spanish migrants at very different ages. Our sample contains information of individuals whose ages when they were measured range from their early teens to their nineties. While the standard growing period of a human being lasts until approximately 18 years, the pace is different for girls and boys. Martínez-Carrión (2005) shows that the most significant changes appear during the first five years of life, when the stature of both girls and boys reveals exactly the same pattern. However, the trends change during puberty, when on average girls grow faster than boys, a situation that is reversed during the last teenage years, when boys catch up and overtake girls. We could have tried to estimate the heights of migrants measured when they were teenagers, adjusted according to their growth potential, but this procedure would have implied several methodological assumptions that are in our opinion untenable. Assuming the same growth potential for all teenagers would also assume that all of them experienced the same living conditions during their childhoods, and therefore that their growth potential when they were measured was also similar. As explained before, an individual who suffered low living standards during the first years of their life could catch up in terms of height during their adolescence. Therefore, the growth potential of the teenagers who entered Mexico could be as diverse as their living conditions in their childhood, and there is no way of knowing the particular case of each immigrant. For this reason, our sample excludes all individuals who were under the age of eighteen when they were measured.

We should also consider that some of the migrants measured when they were adults spent part of their lives as youngsters in Mexico. This problem does not exist for those teenagers who entered Mexico after the Registry was established in 1926, because, as explained in the previous paragraph, they were excluded from our sample. However, those migrants who entered Mexico when they were teenagers (and in some cases even children) before 1926 but were recorded and measured when they were adults could be problematic. In these cases, we do not know the extent to which their stature as adults is consequence of the living standards they enjoyed in Spain or in Mexico. This is important, as this paper attempts to estimate the height of Spanish migrants, and in many of these cases their height would be more a reflection of living conditions in the Mexico where they grew up than of the Spain

\footnotetext{
12 See for instance Baten and Murray (2000) and Hatton and Bray (2010).
} 


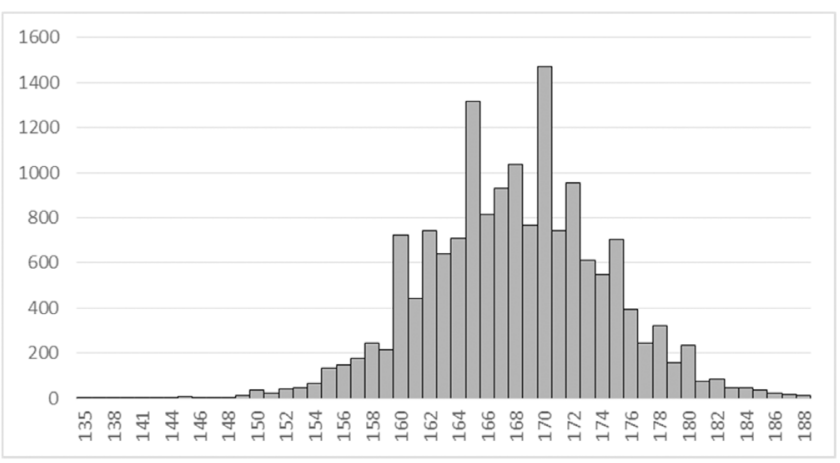

Fig. 7. Distribution of height of male migrants. Source: estimated from National Registry of Foreigners.

they left behind. Not being able to identify the place where they grew up would introduce noise in our estimates of the gender gap, where fixed effects of the province of birth are included as control variable. For that reason, we also decided to exclude these individuals from the final sample.

We also had to introduce adjustments in the statures of older migrants. Anthropometrics literature shows that individuals start to lose stature after the age of 50, mainly as a consequence of the compression of the discs between the vertebrae. Fernihough and McGovern (2015) suggest that on average the decline among older individuals takes place at an annual rate of between 0.08 and 0.1 per cent for males and 0.12 and 0.14 per cent for females. We used the mean of these ranges and applied them to our sample for those individuals older than 50 . This adjustment mostly affects the oldest individuals who moved to Mexico during the second half of the nineteenth century, and who were measured at an older age after the Registry was created in $1926 .{ }^{13}$

Figs. 7 and 8 respectively present the distribution of male and female heights in the sample. In both cases, heights follow a normal distribution that shows, however, peaks of 165 and 170 for men and 160 for women. As in the case of birth years, we believe that these particular peaks are probably a consequence of rounding up the measurement.

\section{Results}

Fig. 9 shows the average height of male migrants to Mexico by decade of birth between the 1840s and 1920s. The solid line shows the average height and the shaded area presents the 90 per cent confidence interval. The series shows an initial increase followed by a period of reduction until the 1880 s, although the wide margins of the confidence interval for those born in the 1840s does not guarantee that the increase was statistically significant. The results from other historical anthropometric studies in Spain support the idea of a decline in average heights in Spain between the 1850s and the 1880s. Martínez-Carrión and Puche Gil (2010) showed that average heights in south east Spain fell during the 1860s and 1870s and grew again during the 1880s. Cámara et al. (2019) suggest a relative stagnation between 1840 and 1880 that would also be compatible with our estimates, followed by a clear increase in average heights of Spanish conscripts that also coincides with our results. Our data show the same increase from the 1880s, which continued until the end of the period when the statures of male

\footnotetext{
13 This adjustment has been followed in the literature (see Blum and Rei, 2018 as example) to take advantage of the information provided by individuals who were measured after the age of 50 , and which, as in this case, can be very relevant when estimating average heights of early cohorts)
}

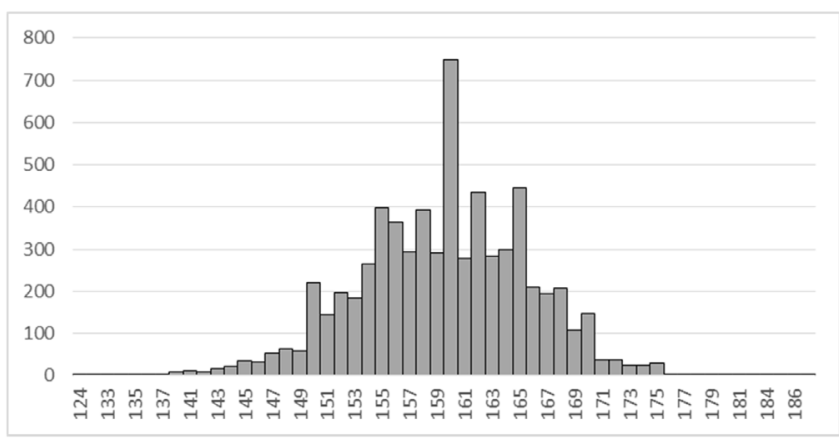

Fig. 8. Distribution of height of female migrants. Source: estimated from National Registry of Foreigners.

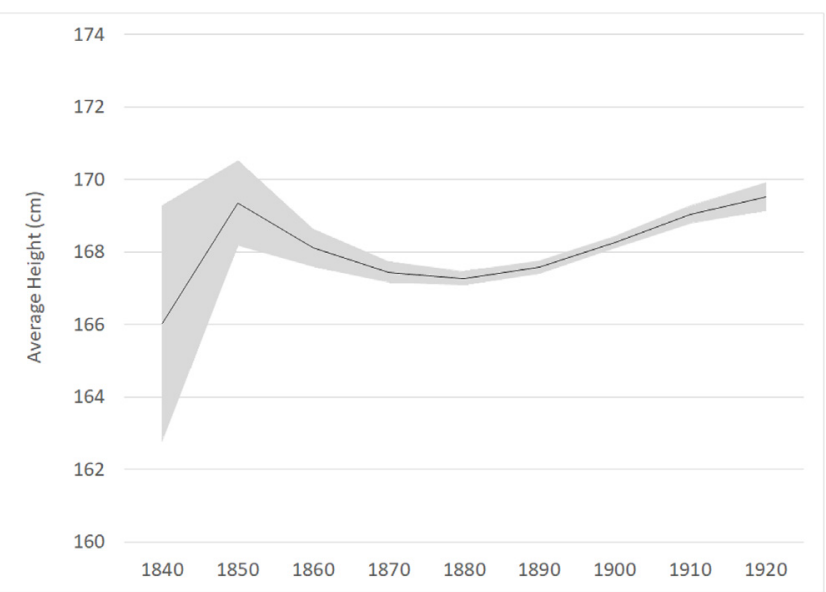

Fig. 9. Average height of men $(\mathrm{cm})$ with 90 per cent confidence intervals by decade of birth, 1840-1920.

Source: estimated from National Registry of Foreigners.

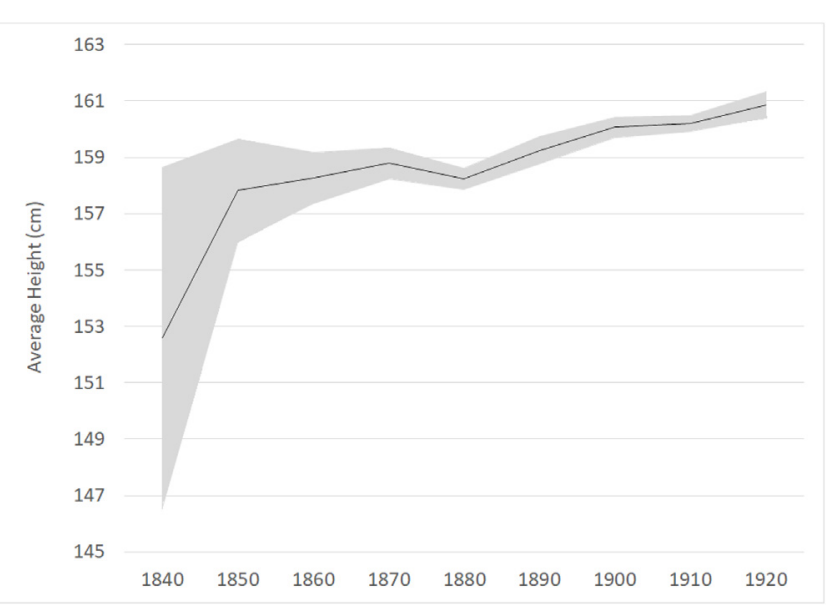

Fig. 10. Average height of women $(\mathrm{cm})$ with 90 per cent confidence intervals by decade of birth, 1840-1920.

Source: estimated from National Registry of Foreigners.

migrants to Mexico reached the maximum value of around 169.5 $\mathrm{cm}$, an increase that is also statistically significant.

The results obtained for women are presented in Fig. 10, and show trends that are very different to those observed for men. The general trend shows a clear success story, with heights that rose from $152.6 \mathrm{~cm}$ in the cohort born in the $1840 \mathrm{~s}$ to the 160.9 
centimetres reached by the migrants born in the 1920s. However, it should also be noted that it was only from the 1880s onwards that we observe a systematic increase that was also statistically significant and that the results for the previous decades are also affected by the wide confidence intervals of the first cohorts affected by a smaller sample size. Although as in the case of men the smaller number of observations in the early decades produces wide confidence intervals, the increase in female heights in the long run is also a statistically significant fact.

The comparison of both series reveals that heights of male and female migrants to Mexico followed very different trends. While the second half of the nineteenth century was a period of shrinking heights for men, it was a period of growth for women. The turn of the century on the other hand also heralded a change in the relative trends, and although heights of women kept rising, this was also the case for men.

The results show that, as suggested by their $A B C C$ index, Spanish migrants to Mexico were selected on the basis of positive discrimination. The average height ranged from $166 \mathrm{~cm}$ in the 1840 birth cohort to 169 in 1920, while the estimates for Spanish recruits by Cámara et al. (2019) range from 162 to 165 in the same cohorts. Comparison with other studies that estimated the height of the elites in Brazil and Colombia corroborates the positive selection of Spanish male migrants, who in the early twentieth century averaged a similar height of around $168 \mathrm{~cm}$ (Meisel and Vega, 2007; Franken, 2019). In the case of women, Spanish female migrants were even taller than women in the elite of Colombia, averaging more than $159 \mathrm{~cm}$ compared to the $158 \mathrm{~cm}$ of their Colombian counterparts in the cohorts born between 1870 and 1920 (Meisel and Vega, 2007) (Table 2).

In order to estimate the gender gap between male and female heights, we used the individual records in an OLS pooled regression. The first specification (Eq. (1)) will simply regress the height of the individual to a female dummy $\left(\right.$ Male $\left._{i}\right)$ and fixed effects by decade $\left(D_{i}\right)$. Although Fig. 5 and Table 1 show that in general both male and females shared the same provinces of origin, the second specification (Eq. (2)) takes into account provincial variations including controls by province of origin $\left(P_{i}\right)$. Another important factor to take into account when estimating the gender gap is the difference in socio-economic status between the men and women included in the sample. The main problem that we found in our source was the difficulty involved in finding information that measures the human capital of every migrant. In the case of males, this can be proxied through their occupations, but this was not possible for the huge majority of women who were recorded as housewives. However, we are aware that a housewife from a wealthy family probably received a much better education than her counterpart from a poorer one. For that reason, we used the number of foreign languages spoken by men and women as a measurement of human capital, as this variable was included in the

Table 2

Average height of men and women $(\mathrm{cm})$ with 90 per cent confidence intervals by decade of birth, 1840-1920.

\begin{tabular}{|c|c|c|c|c|c|c|c|}
\hline \multicolumn{4}{|l|}{ Men } & \multicolumn{4}{|c|}{ Women } \\
\hline & Lower & Mean & Upper & & Lower & Mean & Upper \\
\hline 1840 & 162.8 & 166.0 & 169.3 & 1840 & 146.6 & 152.6 & 158.7 \\
\hline 1850 & 168.2 & 169.4 & 170.5 & 1850 & 156.0 & 157.8 & 159.6 \\
\hline 1860 & 167.6 & 168.1 & 168.6 & 1860 & 157.4 & 158.3 & 159.2 \\
\hline 1870 & 167.2 & 167.4 & 167.7 & 1870 & 158.3 & 158.8 & 159.3 \\
\hline 1880 & 167.1 & 167.3 & 167.5 & 1880 & 157.9 & 158.2 & 158.6 \\
\hline 1890 & 167.4 & 167.6 & 167.8 & 1890 & 158.8 & 159.3 & 159.7 \\
\hline 1900 & 168.1 & 168.3 & 168.4 & 1900 & 159.7 & 160.1 & 160.4 \\
\hline 1910 & 168.8 & 169.0 & 169.3 & 1910 & 159.9 & 160.2 & 160.5 \\
\hline 1920 & 169,2 & 169,5 & 169,9 & 1920 & 160,4 & 160,9 & 161,3 \\
\hline
\end{tabular}

Source: estimated from National Registry of Foreigners. cards for both genders and can be included in our models. We argue that although knowledge of a foreign language represents a very high level of formal education, the high variance between individuals with this ability might allow us capture at least part of the differences in respective human capital. In this case, we had to make some adjustments, as the cards did not specifically refer to foreign languages but to languages other than Castilian Spanish. This implies that in many cases the cards included languages like Catalan or Basque that could be native to the migrants' regions of origin. We excluded all these cases and recorded in the variable only those languages that were foreign and that therefore required, in principle, an investment in human capital in order to be mastered. Therefore, the third specification includes the number of foreign languages spoken as control variable (Eq. (3)). After examining the value of the gender gap in the whole sample with the three first models, the final specification (Eq. (4)) estimates changes in the gender gap over time, interacting the female dummy with the fixed effect in every decade in order to capture the size of the gender gap by decade of birth.

Height $_{i}=\propto+\beta_{1}$ Male $_{i}+D_{i}+\varepsilon_{i}$

Height $_{i}=\propto+\beta_{1}$ Male $_{i}+D_{i}+P_{i}+\varepsilon_{i}$

Height $_{i}=\propto+\beta_{1}$ Male $_{i}+\beta_{2}$ Languages $_{i}+D_{i}+P_{i}+\varepsilon_{i}$

Height $_{i}=\propto+\beta_{2}$ Languages $_{i}+\beta_{3}$ Male $_{i} * D_{i}+D_{i}+P_{i}+\varepsilon_{i}$

Table 3 presents the summary statistics of the sample. The average height for males was $8.5 \mathrm{~cm}$ higher than for females, and male migrants were also measured at a slightly older age than women, 38.7 versus 37.9 years. Although these results are not surprising, analysis of the number of foreign languages offers some interesting insights. As explained above, 'housewife' was the category employed in the vast majority of cases to record the occupation of women, a vague definition that renders difficult its use to analyse the differences in human capital between women. However, Table 3 shows that the average number of foreign languages spoken by male immigrants was 0.23 , a number that was not very different to the 0.21 average estimated for women. The standard deviation for both genders was also very similar, revealing that the differences in human capital between women were as high as the differences between men. These results highlight the importance of identifying human capital estimators available for both genders, as the common use of occupations could hinder the correct identification of the education levels of women. Given the high level of human capital required to master a foreign language at the time, these results suggest that, as in the case of men, female migrants were also highly skilled. It also shows that the diversity within women in terms of human capital was far larger than could be observed via analysis of their occupations, a variance that helps us to identify better the gender gap after controlling by human capital differences within female migrants.

Table 4 shows the results of the four models described above. Analysis of the overall gender gap in models I-III shows that on average women were around 8.7-8.8 centimetres shorter than men during the whole period. Given the similar provincial distribution of male and female migrants, the introduction of fixed effects by province of birth did not significantly change results. As expected, men and women with a higher level of human capital were also taller, specifically, 1.1-1.2 centimetres taller for every additional foreign language that they spoke.

Model IV allows us to analyse the evolution of the gap over time. Fig. 11 presents the results of the coefficients for the interactions between the female dummy and the fixed effects by decade, including 90 per cent confidence intervals. Our results suggest that, 
Table 3

Descriptive Statistics.

\begin{tabular}{|c|c|c|c|c|c|c|c|c|}
\hline \multicolumn{3}{|l|}{ Height } & \multicolumn{3}{|l|}{ Age } & \multicolumn{3}{|c|}{ Foreign Languages } \\
\hline Percentiles & Men & Women & Percentiles & Men & Women & Number & $\begin{array}{l}\text { Men } \\
\text { Percentage }\end{array}$ & Women \\
\hline 1 & 153 & 144 & 1 & 18 & 18 & 0 & 83.0 & 83.3 \\
\hline 5 & 158 & 150 & 5 & 20 & 20 & 1 & 12.2 & 13.2 \\
\hline 10 & 160 & 151 & 10 & 24 & 22 & 2 & 3.8 & 2.8 \\
\hline \multirow[t]{2}{*}{25} & 164 & 155 & 25 & 29 & 27 & 3 & 0.9 & 0.6 \\
\hline & & & & & & $>4$ & 0.2 & 0.0 \\
\hline \multirow[t]{2}{*}{50} & 168 & 160 & 50 & 37 & 35 & & & \\
\hline & & & & & & Mean & 0.23 & 0.21 \\
\hline 75 & 172 & 164 & 75 & 47 & 46 & Std. Dev. & 0.57 & 0.51 \\
\hline 90 & 176 & 167 & 90 & 56 & 57 & & & \\
\hline 95 & 178 & 169 & 95 & 61 & 64 & & & \\
\hline 99 & 184 & 174 & 99 & 71 & 75 & & & \\
\hline Lowest & 135 & 124 & Lowest & 18 & 18 & & & \\
\hline Highest & 197 & 192 & Highest & 92 & 100 & & & \\
\hline Mean & 168.0 & 159.5 & Mean & 38.7 & 37.9 & & & \\
\hline Std. Dev. & 6.3 & 6.3 & Std. Dev. & 12.5 & 13.5 & & & \\
\hline
\end{tabular}

Source: estimated from National Registry of Foreigners.

Table 4

Determinants of heights.

\begin{tabular}{|c|c|c|c|c|}
\hline Dep. variable: Height $(\mathrm{cm})$ & Model I & Model II & Model III & Model IV \\
\hline Male & $8.7^{* * *}(0.09)$ & $8.7^{* * *}(0.09)$ & $8.8^{* * *}(0.10)$ & \\
\hline Languages spoken & & $1.2^{* * *}(0.08)$ & $1.1^{* * *}(0.09)$ & $1.1^{* * *}(0.09)$ \\
\hline \multicolumn{5}{|l|}{ Decade born $*$ Male } \\
\hline $1840 \mathrm{~s}$ & & & & $15.0^{* * *}(1.90)$ \\
\hline $1850 s$ & & & & $10.8^{* * *}(1.35)$ \\
\hline $1860 s$ & & & & $9.5^{* * *}(0.66)$ \\
\hline $1870 s$ & & & & $8.7^{* * *}(0.40)$ \\
\hline $1880 \mathrm{~s}$ & & & & $9.0^{* * *}(0.27)$ \\
\hline $1890 \mathrm{~s}$ & & & & $8.6^{* * *}(0.22)$ \\
\hline $1900 \mathrm{~s}$ & & & & $8.6^{* * *}(0.18)$ \\
\hline $1910 \mathrm{~s}$ & & & & $9.1^{* * *}(0.23)$ \\
\hline $1920 s$ & & & & $9.0^{* * *}(0.37)$ \\
\hline $1930 s$ & & & & $11.2^{* * *}(1.8)$ \\
\hline Decade of birth control & Yes & Yes & Yes & Yes \\
\hline Province of origin control & No & No & Yes & Yes \\
\hline Constant & 155.6 & 155.0 & 154.8 & 150.5 \\
\hline Obs. & 22,560 & 22,404 & 20,427 & 20,427 \\
\hline R2 & 0.28 & 0.29 & 0.30 & 0.30 \\
\hline F-test & 0.00 & 0.00 & 0.00 & 0.00 \\
\hline
\end{tabular}

Notes: *** and ${ }^{* * *}$ denote significance at 10,5 and 1 per cent levels, respectively. Robust standard errors in parentheses.

as expected from analysis of the individual series, the gender gap in the biological standard of living decreased between the $1840 \mathrm{~s}$ and the 1890 s from $15 \mathrm{~cm}$ in the 1850 s to 8.6 in the $1890 \mathrm{~s}$. This was possible thanks to the increase in height of female migrants who were able to catch up with men during the initial decades of the period. The evolution of the gap during the twentieth century is less clear. Both male and female heights increased and the gap remained relatively stable. Taking into account the 90 per cent confidence levels, we could conclude that the gender gap was reduced during the first half of the period, while the small changes that followed the 1890s always fell within the interval.

The results are also consistent with other studies on historical sexual dimorphism, like the case of England and Wales, where the gender gap decreased from the late nineteenth century to the early twentieth, before subsequently rising (Cámara, 2018). For an idea of how large or small the gender gap in heights was, we can compare it with the values in contemporary male and female heights in Spain. Spijker et al. (2012) estimated at $175.3 \mathrm{~cm}$ the height of males born in Spain between 1966 and 1976, and at

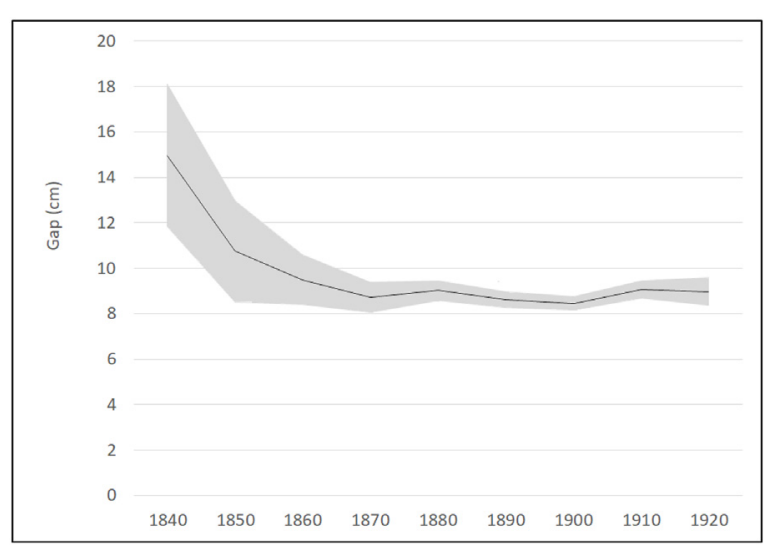

Fig. 11. Gender gap in heights $(\mathrm{cm})$ with 90 per cent confidence intervals by decade of birth, 1840-1920.

Source: estimated from National Registry of Foreigners. 


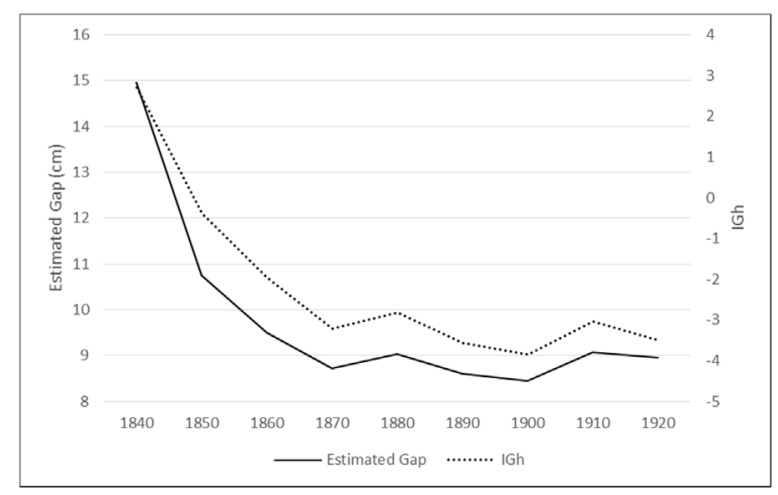

Fig. 12. Gender inequality of height measure (IGh) and gap in heights, 1840-1920. Source: estimated from National Registry of Foreigners.

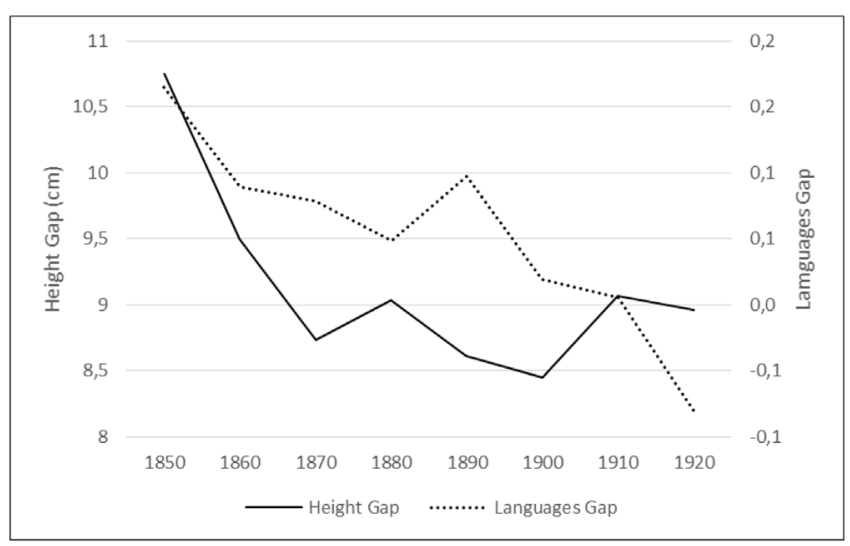

Fig. 13. Gender gap in foreign languages and gap in heights, 1840-1920. Source: estimated from National Registry of Foreigners.

$163 \mathrm{~cm}$ the average height of women born in the same cohort. Therefore, they observed a gap of more than $12 \mathrm{~cm}$, which is larger than the one that we observe in the cohorts born a century ago. As a result, women are today around 7 per cent shorter than their male counterparts, compared to the 5 per cent gap that existed in the early twentieth century.

How does our estimate of sexual dimorphism compare to other alternatives suggested by the literature? Recent research on gender differences using anthropometrical data has pointed to the use of alternative estimators like the gender inequality of height (Schwekendiek and Baten, 2019). ${ }^{14}$ Fig. 12 presents the evolution of this proxy and the gender gap we estimated between 1840 and 1920 , showing identical trends.

We can also compare the evolution of the gender gap in the biological living standard with the gap in other proxies of welfare, such as human capital. We used the information available in the records related to the number of foreign languages spoken by both men and women. Although as explained above this proxy probably captures a high level of human capital, we also believe that learning foreign languages requires natural skills that could also identify a level of human capital beyond formal education. Fig. 13 presents the evolution of the gender gap in heights and the gender gap in foreign languages spoken per migrant by decade of birth. Although the series do not correlate in the short term, the same

\footnotetext{
14 The gender inequality of height measure is estimated using the following equation $\mathrm{GIh}=\mathrm{Hm}-\mathrm{Hf}-(-33.75+0.276 * \mathrm{Hmf})$ where $\mathrm{Hm}$ and $\mathrm{Hf}$ represent male and female heights respectively and $\mathrm{Hmf}$ the average height of both genders.
}

long-term decline can be observed in the gender gap for both series from the mid-nineteenth to the early twentieth century.

\section{Conclusions}

The study of human heights has become a popular field, in which economic historians have combined their expertise with natural sciences in order better to understand the evolution of living standards in the past. This paper has sought to make a new contribution to the literature by estimating the average height of male and female Spanish migrants to Mexico during the late nineteenth and the early twentieth century. We used the National Registry of Foreigners in Mexico, which includes information about all the migrants who lived in Mexico in the 1920s and those who entered the country subsequently. One of the Registry's special characteristics is the inclusion in the records of the migrants' height, and crucially, that of women too. From the study of thousands of personal records, we were able to estimate the evolution of height of the Spanish migrants in Mexico born between the mid-nineteenth century and the 1930s.

Our results show that although in the long run the average heights of male and female migrants to Mexico increased, they followed very different paths. The average height of male migrants decreased for the cohorts born in the 1850 s and 1880 s, followed by a period of slow recovery during the 1880 s and 1890 s. It was at the turn of century when the height of male migrants rose at a higher rate. In the case of women, our estimations show that height of female migrants increased more systematically during the whole period analysed, with stagnation in the 1880 s and 1910s. The comparison with the height of Spanish conscripts and Latin American elites shows that, as suggested by the literature, Spanish migrants to Mexico were a highly qualified group with a strong positive selection.

The different trends followed by men and women meant that the gender gap also underwent important changes. The difference in height between male and female migrants peaked in the $1840 \mathrm{~s}$ and declined in the long run. Women born around 1900 reduced the gender gap to its lowest point, when male migrants were just 5.6 per cent taller than their female counterparts. This situation is particularly interesting when we compare this gap with the difference that exists today in Spain, when males are eight per cent taller than women. The process of convergence from the late nineteenth century coincided in time with the modernisation of the country, when Spain experienced some of the most intense economic and institutional changes in its history. The use of alternative measurements of the gender gap employing anthropometric data or human capital proxies shows very similar results, with a clear reduction of gender differences from the midnineteenth to the early twentieth century.

\section{Author statement}

Carlos Santiago-Caballero as only author has been responsible all of the work carried out in this article.

\section{Declaration of Competing Interest}

The authors report no declarations of interest.

\section{Acknowledgements}

I would like to thank the members of the Economic History Department of the LSE for their support in writing this article, with particular thanks for their collaboration during a research visit funded by the Carlos III University. I also appreciate the help received from three anonymous referees and the work of the editor, Professor Jörg Baten. 


\section{Appendix A}

See Fig. A1

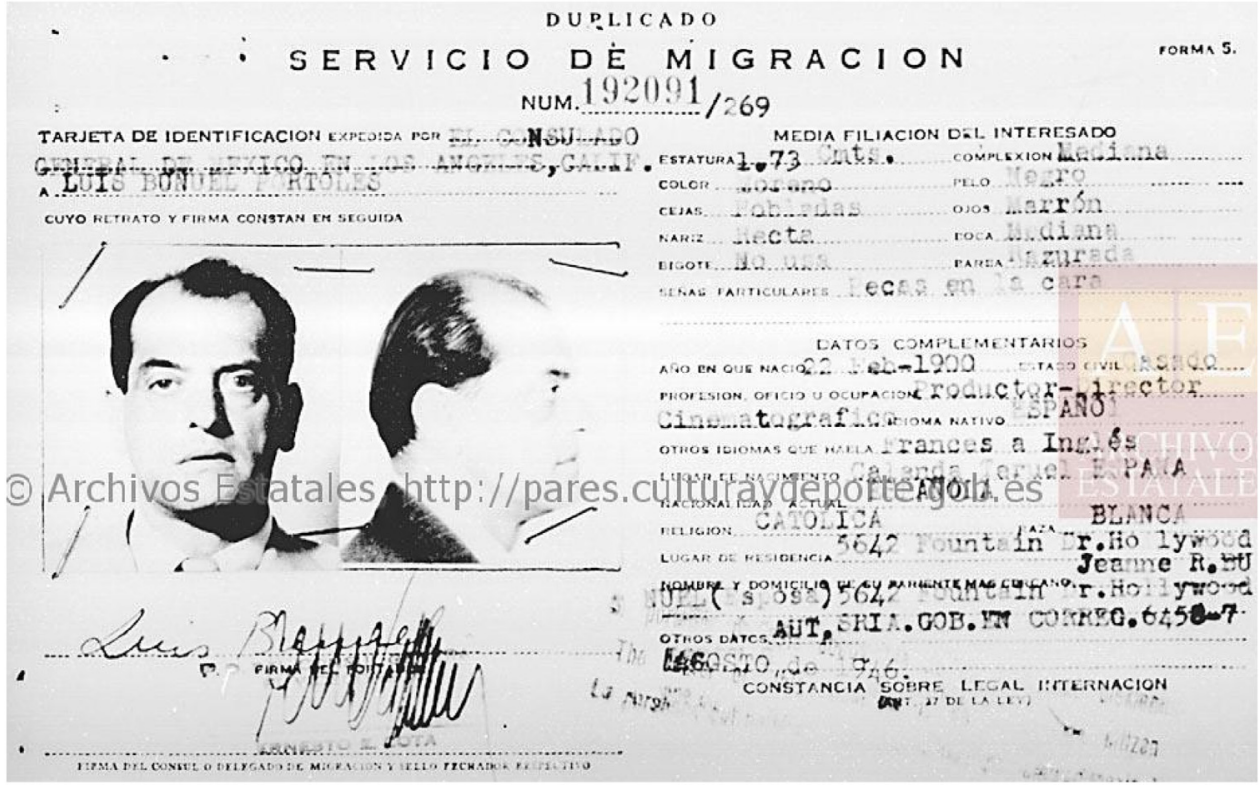

Source: PARES (http://pares.culturaydeporte.gob.es/inicio.html).

Fig. A1. Example of card.

\section{References}

A'Hearn, B., 2003. Anthropometric evidence on living standard in Northern Italy, 1730-1860. J. Econ. Hist. 63 (2), 351-381.

Baten, J., Murray, J.E., 2000. Heights of Men and Women in 19th-Century Bavaria: Economic, Nutritional, and Disease Influences. Explor. Econ. Hist. 37, 351-369.

Blum, M., Rei, C., 2018. Escaping Europe: health and human capital of Holocaust refugees. Eur. Rev. Econ. Hist. 22 (1), 1-27.

Bodzsár, É., Susanne, C. (Eds.), 1998. Secular Growth Changes in Europe. Eötvös University Press, Budapest.

Bogin, B., Keep, R., 1999. Eight thousand years of economic and political history in Latin American revealed by anthropometry. Ann. Hum. Biol. 26, 333-351.

Bozzoli, C., Deaton, A.S., Quintana-Domeque, C., 2009. Child Mortality, Income and Adult Height. Demography 76, 647-669.

Cámara, A.D., 2009. Long-term trends in height in rural Eastern Andalucía (17501950). Hist. Agrar. 47, 45-67.

Cámara, A.D., 2018. Sobre la asociación entre el dimorfismo sexual en estatura y el estado nutricional de hombres y mujeres en el largo plazo. Nutr. Hosp. 35 (5), 123-128.

Cámara, A.D., Martínez-Carrión, J.M., Puche, J., Ramon-Muñoz, J., 2019. Height and inequality in Spain: a long-term perspective. Revista de Historia Económica Journal of Iberian and Latin American Economic History 37, 205-238.

Case, A., Paxson, C., 2008. Height, health and cognitive function at older ages. Am. Econ. Rev. 98 (2), 463-467.

Deaton, A., Arora, R., 2009. Life at the top: the benefits of height. Econ. Hum. Biol. 7 (2), 133-136.

Federico, G., 2003. Heights, calories and welfare: a new perspective on Italian industrialization, 1854-1913. Econ. Hum. Biol. I (3), 289-308.

Fernihough, A., McGovern, M.E., 2015. Physical stature decline and the health status of the elderly population in England. Econ. Hum. Biol. 16, 30-44.

Floud, R.C., 1994. The heights of Europeans since 1750: a new source for European economic history. In: Komlos, J. (Ed.), Stature, Living Standard, and Economic Development. Essays in Anthropometric History. The University of Chicago Press, Chicago, pp. 9-24.

Floud, R., Wachter, K.W., 1982. Poverty and physical stature: evidence on the standard of living of London boys 1770-1870. Soc. Sci. Hist. 6 (4), 422-452.

Floud, R.C., Watcher, K.W., Gregory, A.S., 1990. Height, Health and History: Nutritional Status in Britain, 1750-1980. Cambridge University Press, Cambridge.

Floud, R., Fogel, R.W., Harris, B., Hong, S.C., 2011. The Changing Body: Health, Nutrition, and Human Development in the Western World Since 1700. University Press, Cambridge.

Fogel, R.W., 1995. Anthropometric history: notes on the first two decades of a new field of research. In: Hauspie, R., R. Lindgren, G., Falkner, F. (Eds.), Essays on
Auxology Presented to James M. Tanner. Castlemead, Welwyn Garden City, pp. 271-284.

Franken, D.W., 2019. Anthropometric history of Brazil, 1850-1950: insights from military and passport records. Revista de Historia Económica / Journal of Iberian and Latin American Economic History 37, 377-408.

Galofré-Vilà, G., 2018. Growth and maturity: a quantitative systematic review and network analysis in anthropometric history. Econ. Hum. Biol. 28, 107-118.

Garcia-Montero, H., 2009. Antropometría y niveles de vida en el Madrid rural, 18371915. Hist. Agrar. 47, 95-117.

Gomez Mendoza, A., Perez Moreda, V., 1995. Heights and welfare in Spain, 19001930. In: Komlos, J. (Ed.), The Biological Standard of Living on Three Continents: Further Explorations in Anthropometric History. Westview Press, Boulder, pp. 81-94.

Guntupalli, A., Baten, J., 2009. Measuring gender well-being with biological welfare indicators. In: Harris, B., Galvez, L., Machado, H. (Eds.), Gender and Well-Being in Europe. Historical and Contemporary Perspectives. Asghate, Farnham, pp. 43-58.

Harris, B., 2009. Anthropometric history, gender and the measurement of wellbeing. In: Harris, B., Galvez, L., Machado, H. (Eds.), Gender and Well-Being in Europe. Historical and Contemporary Perspectives. Ashgate, Farnham, pp. 59-84.

Hatton, T.J., Bray, B.W., 2010. Long run trends in the heights of european men, 19th20th centuries. Econ. Hum. Biol. 8, 405-413.

Hatton, T.J., Martin, R.M., 2010. Fertility decline and the heights of children in Britain, 1886-1938. Explor. Econ. Hist. 47, 505-519.

Kelly, I., Baten, J., 2019. Introduction to the Special Issue in Honor of John Komlos, the Founding Editor of Economics and Human Biology. Econ. Hum. Biol. 34, 1-4.

Koepke, N., Baten, J., 2005. The biological standard of living in Europe during the last two millennia. Eur. Rev. Econ. Hist. 9, 61-95.

Komlos, J., 1989. Nutrition and Economic Development in the 18th Century Habsburg Monarchy. An Anthropometric History. Princeton University Press, Princeton.

Komlos, J. (Ed.), 1995. The Biological Standard of Living on Three Continents: Further Explorations in Anthropometric History. Westview Press, Boulder.

Komlos, J., 2009. Anthropometric history: an overview of a quarter century of research. Anthropol. Anzeiger 67 (4), 341-356.

Komlos, J., Baten, J., 1998. The Biological Standard of Living in Comparative Perspective. Franz Steiner, Stuttgart.

Lida, C.E., Pacheco Zamudio, P., 1994. El perfil de una inmigración: 1821-1939. In: lonlLida, C.E. (Ed.), Una Inmigración Privilegiada. Comerciante, Empresarios y Profesionales españoles en México en los siglos XIX y XX. Alianza Editorial, Madrid, pp. 25-51.

María-Dolores, R., Martínez-Carrión, J.M., 2011. The relationship between height and economic development in Spain, 1850-1958. Econ. Hum. Biol. 9, 30-44. 
Martinez Carrión, J.M., 2001. Estatura, salud y bienestar en las primeras etapas del crecimiento económico español. Una perspectiva comparada de los niveles de vida. Documento de trabajo No 0102. Asociación Española de Historia Económica.

Martínez-Carrión, J.M., 1986. Estatura, nutrición y nivel de vida en Murcia, 18601930. Revista de Historia Económica 4 (1), 67-99.

Martínez-Carrión, J.M., 1991. La estatura humana como un indicador del bienestar económico: un test local en la España del siglo XIX. Boletín de la Asociación de Demografía Histórica IX (2), 51-78.

Martínez-Carrión, J.M., 1994. Stature, welfare and economic growth in nineteenth century Spain: the case of Murcia. In: Komlos, J. (Ed.), Stature, Living Standards and Economic Development: Essays in Anthropometric History. University of Chicago Press, Chicago, pp. 76-89.

Martínez-Carrión, J.M., 2005. Estaturas, desigualdad regional y desarrollo económico en Italia y España durante el siglo XX. Mediterráneo e Historia Económica 7, 67-99.

Martínez-Carrión, J.M., Moreno-Lázaro, J., 2007. Was there an urban height penalty in Spain, 1840-1913? Econ. Hum. Biol. 5 (1), 144-164.

Martínez-Carrión, J.M., Puche Gil, J., et al., 2010. La estatura de los españoles al final de la adolescencia. Una historia antropométrica. In: Chastagnaret, G. (Ed.), Los niveles de vida en España y Francia (Siglos XVIII-XX). Universidad de Alicante, Alicante, pp. 147-188.

Martínez-Carrión, J., Salvatore, R., 2019. Inequality and well-being in Iberian and Latin American regions since 1820 . New approaches from anthropometric history. Revista de Historia Económica / Journal of Iberian and Latin American Economic History 37 (2), 193-204.

Martínez-Carrión, J.M., Pérez-Castroviejo, P.M., Gil, J.P., Ramon-Muñoz, J.M., 2014. La brecha rural-urbana de la estatura y el nivel de vida al comienzo de la industrialización española. Historia social 80, 35-57.

Martínez-Carrión, J.M., Cámara, A.D., Ramon-Muñoz, J.M., 2018. Nutrición y desigualdad en el largo plazo: ¿qué enseña la historia antropométrica sobre España? Nutr. Hosp. 35 (5), 1-10.

Meisel, A., Vega, M., 2007. The Biological Standard of Living (and Its convergence) in Colombia, 1870-2003: A Tropical Success Story. Econ. Hum. Biol. 5 (1), 100-122.

Murasko, J.E., 2020. Height, marriage, and partner characteristics for women in lowand middle-income countries. Econ. Hum. Biol. 38

Nicholas, S., Steckel, R.H., 1991. Heights and living standards of english workers during the early years of industrialization, 1770-1815. J. Econ. Hist. 51 (4), 937-957.
Pla Brugat, D., 2001. La presencia española en México, 1930-1990: caracterización e historiografía. Migraciones \& Exilios: Cuadernos de la Asociación para el estudio de los exilios y migraciones ibéricos contemporáneos 2, 157-188.

Prados de la Escosura, L., Santiago-Caballero, C., 2020. The Napoleonic Wars: A Watershed in Spanish History. CEPR Discussion Papers DP15616 December 2020.

Quiroga, G., 1998. Height evolution in Spain, 1893-1954. An analysis by regions and professions. In: Komlos, J., Baten, J. (Eds.), The Biological Standard of Living in Comparative Perspective. Franz Steiner, Stuttgart, pp. 359-383.

Quiroga, G., 2001. Estatura, diferencias regionales y sociales t niveles de vida en España (1893-1954). Revista de Historia Económica XIX, 175-200.

Quiroga, G., 2002. Estatura y condiciones de vida en el mundo rural español, 18931954. In: Martínez Carrión, J.M. (Ed.), El nivel de vida en la España rural, siglos XVIII-XX. Publicaciones de la Universidad de Alicante, Alicante, pp. 461-495.

Quiroga, G., 2003. Literacy, education and welfare in Spain (1893-1954). Paedagog. Hist. 39 (5), 599-619.

Ramón-Muñoz, J.M., 2009. Bienestar biológico y crecimiento agrario en la Cataluña rural, 1840-1936. Hist. Agrar. 47, 119-142.

Sánchez-Alonso, B., 2019. The age of mass migration in Latin America. Econ. Hist. Rev. 72 (1), 3-31.

Sandberg, L., Steckel, R.H., 1980. Soldier, Soldier, What Made you Grow so Tall? A Study on Height, Health and Nutrition m Sweden, 1720-1881. Econ. Hist. 23 (2), 91-105.

Spijker, J.J., Cámara, A.D., Blanes, A., 2012. The health transition and biological living standards: adult height and mortality in 20th-century Spain. Econ. Hum. Biol. 10 (3), 276-288.

Steckel, R.H., 1979. Slave height profiles from coastwise manifests. Exp. Econ. Hist. $16,363-380$.

Steckel, R.H., 1983. Height and per capita income. Hist. Methods 16, 1-7.

Steckel, R.H., 1995. Stature and the standard of living. J. Econ. Lit. 33, 1903-1940.

Steckel, R.H., 2008. Biological measures of the standard of living. J. Econ. Perspect. 22 (1), 129-152.

Steckel, R.H., 2009. Heights and human welfare: recent developments and new directions. Explor. Econ. Hist. 46 (1), 1-23.

Steckel, R.H., Rose, J.R., 2002. The Backbone of History. Health and Nutrition in the Western Hemisphere. Cambridge University Press, Cambridge, UK

Van Leeuwen, M.H.D., Maas, I., 2011. HISCLASS. A Historical Internationalsocial Class Scheme. Leuven University Press, Leuven. 